\title{
Generation of induced cardiac progenitor cells via somatic reprogramming
}

\author{
Jianyong $X \mathbf{u}^{1,2,3}$, Wei Lian ${ }^{1,2,3}$, Lingyun $\mathbf{L i}^{1,2,3}$ and Zhong Huang ${ }^{1,2,3}$ \\ ${ }^{1}$ Institute of Biological Therapy, Shenzhen University, Shenzhen, China \\ 2 Department of Pathogen Biology and Immunology, Shenzhen University School of Medicine, Shenzhen, China \\ ${ }^{3}$ Shenzhen City Shenzhen University Immunodiagnostic Technology Platform, Shenzhen, China \\ Correspondence to: Jianyong XU, email: xujianyong820915@163.com \\ Zhong Huang, email: zhuang809@126.com \\ Keywords: cardiac progenitor cell, CPC, somatic reprogramming, induced CPC \\ Received: November 30, $2016 \quad$ Accepted: January 24, $2017 \quad$ Published: February 10, 2017
}

Copyright: Xu et al. This is an open-access article distributed under the terms of the Creative Commons Attribution License (CC-BY), which permits unrestricted use, distribution, and reproduction in any medium, provided the original author and source are credited.

\section{ABSTRACT}

It has been demonstrated that cardiac progenitor cells (CPCs) represent a more effective cell-based therapy for treatment of myocardial infarction. Unfortunately, their therapeutic application is limited by low yield of cell harvesting, declining quality and quantity during the ageing process, and the need for highly invasive heart biopsy. Therefore, there is an emerging interest in generating CPC-like stem cells from somatic cells via somatic reprogramming. This novel approach would provide an unlimited source of stem cells with cardiac differentiation potential. Here we would firstly discuss the different types of CPC and their importance in stem cell therapy for treatment of myocardial infarction; secondly, the necessity of generating induced CPC from somatic cells via somatic reprogramming; and finally the current progress of somatic reprogramming in cardiac cells, especially induced CPC generation.

Cardiovascular diseases (CVD) are the most prevalent diseases in the world and are associated with significant morbidity and mortality [1]. Myocardial infarction (MI) due to blockade of coronary arteries causing myocardial injuries is the most common cause of CVD. After MI, there is progressive cardiac remodelling, which can lead to left ventricular dilatation and heart failure [2].

Cell-based therapy has been proposed as a promising strategy for treating MI and adverse heart remodelling. Transplantation of healthy and functional cells would replenish the damaged cells and repair the injured heart [3]. Different types of cells, including skeletal myoblasts, bone marrow stem cells (BMSCs), mesenchymal stem cells (MSCs), endothelial progenitor cells (EPCs), cardiomyocytes, and cardiac progenitor cells (CPCs), have been studied for treating MI [4-8]. Because of the potential arrhythmia risk of skeletal myoblasts and cardiomyocytes for treating MI, they are not discussed here $[9,10]$. BMSCs, MSCs and EPCs have been demonstrated effective for treating MI. However, their direct involvement in cardiac regeneration with cardiomyocyte differentiation is controversial [6]. On the other hand, CPCs are safer and more effective compared to BMSCs, MSCs and EPCs for treating MI, with evidences of direct cardiac differentiation [6].

\section{CARDIAC PROGENITOR CELLS}

CPCs (Cardiac Progenitor Cells) are localised in the heart. They have the abilities of self-renewing and differentiating into cardiomyocytes, endothelial cells and smooth muscle cells (the three major cell types of the heart) $[11,12]$. CPCs have become an important player in cardiac homeostasis under both physiological (continual cellular turnover) and pathological (proliferative activity and regenerative potential) conditions. Since the first demonstration of CPCs as the c-Kit ${ }^{+}$Lin $^{-}$population [11], different kinds of CPCs have been identified (Figure 1, Table 1), including $\mathrm{Flk}^{+}[13,14], \mathrm{Sca}^{+}$[15], side population [16, 17], $\mathrm{Mesp}^{+}[18,19]$, Is11 ${ }^{+}[20-22]$, $\mathrm{Nkx} 2.5^{+}[23], \mathrm{Wt1}^{+}[24,25]$ and cardiospheres [26]. 
Table 1: Comparison of resident cardiac progenitor cells

\begin{tabular}{|c|c|c|c|c|c|c|c|c|c|}
\hline Cell Type & Markers & $\begin{array}{l}\text { Developmental } \\
\text { Origin }\end{array}$ & $\begin{array}{l}\text { Self } \\
\text { Renewal }\end{array}$ & Clonality & $\begin{array}{l}\text { Differe } \\
\text { Potent }\end{array}$ & tiation & \begin{tabular}{|l|} 
Functional \\
Characterization in \\
vitro
\end{tabular} & $\begin{array}{l}\text { Function in } \\
\text { vivo }\end{array}$ & Reference \\
\hline cKit+Lin- & $\begin{array}{l}\text { cKit+; Nkx2.5low; } \\
\text { Gata4low; Mef2clow; } \\
\text { CMC marker low; } \\
\text { CD34-; CD45-; CD20- } \\
\text {; CD8-; EC Marker-; } \\
\text { SMC Marker-; Lin- }\end{array}$ & ND & Yes & Yes & $\begin{array}{l}\text { CMC; } \\
\text { EC }\end{array}$ & $\mathrm{SMC}$ & $\begin{array}{l}\text { CMC markers; } \\
\text { sarcomere markers; } \\
\text { action potential }\end{array}$ & $\begin{array}{l}\text { Function } \\
\text { improvement } \\
\text { of the } \\
\text { infarcted } \\
\text { heart with } \\
\text { regeneration }\end{array}$ & {$[11]$} \\
\hline Flk1+ & $\begin{array}{l}\text { Flk1+; Mesp1+; Is11+; } \\
\text { Nkx2.5+ }\end{array}$ & ND & Yes & Yes & $\begin{array}{l}\mathrm{CMC} ; \\
\mathrm{EC}\end{array}$ & SMC; & $\begin{array}{ll}\text { CMC markers; } \\
\text { sarcomere markers; } \\
\text { action potential; } \\
\text { spontaneous } \\
\text { contraction }\end{array}$ & ND & {$[13 ; 14]$} \\
\hline Sca1+ & $\begin{array}{l}\text { Sca1+; Gata4+; CD38+; } \\
\text { CD31+; Mef2c+; } \\
\text { CD34-; Nkx2.5-; cKit- } \\
\text {; Flk1/Flt1-; CD45-; } \\
\text { vWF-; Lin-; CMC } \\
\text { Marker- }\end{array}$ & ND & ND & ND & $\mathrm{CMC}$ & & $\begin{array}{l}\text { CMC markers; } \\
\text { sarcomere markers }\end{array}$ & $\begin{array}{l}\text { Engrafted into } \\
\text { the infarcted } \\
\text { myocardium }\end{array}$ & {$[15]$} \\
\hline $\begin{array}{l}\text { Side } \\
\text { Population }\end{array}$ & $\begin{array}{l}\text { Abcg2+; Sca1+; } \\
\text { CD31+; Mef2c+; cKit-; } \\
\text { CD45-; CD34-; Nkx2.5- } \\
\text {; Gata4-; CMC Marker- }\end{array}$ & ND & Yes & Yes & $\mathrm{CMC}$ & & $\begin{array}{ll}\text { CMC } & \text { markers; } \\
\text { sarcomere } & \text { markers; } \\
\text { calcium transient; } & \text { spontaneous } \\
\text { contraction }\end{array}$ & $\begin{array}{l}\text { Engrafted into } \\
\text { the infarcted } \\
\text { myocardium }\end{array}$ & {$[16,17]$} \\
\hline Mesp1+ & $\begin{array}{lr}\text { Mesp1+; } & \text { Nkx2.5+; } \\
\text { Hand2+; } & \text { Gata4+; } \\
\text { CXCR4+; } & \text { Flk1+; } \\
\text { PDGFRa+ } & \end{array}$ & $\begin{array}{l}\text { Mesp1+ cells } \\
\text { contribute to } \\
\text { the whole heart } \\
\text { development by } \\
\text { lineage tracing } \\
\text { analysis }\end{array}$ & Yes & Yes & $\begin{array}{l}\mathrm{CMC} \\
\mathrm{EC}\end{array}$ & SMC; & $\begin{array}{l}\text { CMC markers; } \\
\text { sarcomere markers; }\end{array}$ & $\begin{array}{l}\text { Engrafted into } \\
\text { the infarcted } \\
\text { myocardium }\end{array}$ & {$[18,19]$} \\
\hline Isl1+ & $\begin{array}{l}\text { Isl1+; Nkx2.5+;Gata4+; } \\
\text { Sca1-; cKit-; CD31-; } \\
\text { CMC Markers-; SMC } \\
\text { markers- }\end{array}$ & $\begin{array}{l}\text { Isl1+ r cells } \\
\text { contribute to } \\
\text { the recond } \\
\text { heart rield } \\
\text { development by } \\
\text { lineage tracing } \\
\text { analysis }\end{array}$ & Yes & Yes & $\begin{array}{l}\mathrm{CMC} \text {; } \\
\mathrm{EC}\end{array}$ & SMC; & $\begin{array}{ll}\text { CMC } & \text { markers; } \\
\text { sarcomere } & \text { markers; } \\
\text { action } & \text { potential; } \\
\text { calcium transient; } & \text { spontaneous } \\
\text { contraction } & \end{array}$ & ND & $\begin{array}{l}{[20, \quad 21,} \\
22]\end{array}$ \\
\hline Nkx2.5+ & $\begin{array}{l}\text { Nkx2.5+; Isl1+; cKit+; } \\
\text { Sca1+; Lin-; EC } \\
\text { Marker- }\end{array}$ & $\begin{array}{l}\text { Nkx2.5+ cells } \\
\text { contribute to } \\
\text { the whole heart } \\
\text { development by } \\
\text { lineage tracing } \\
\text { analysis }\end{array}$ & Yes & Yes & $\mathrm{CMC}$ & $\mathrm{MC}$ & $\begin{array}{l}\text { CMC markers; } \\
\text { sarcomere markers; } \\
\text { action potential; } \\
\text { spontaneous } \\
\text { contraction }\end{array}$ & $\begin{array}{l}\text { Engrafted into } \\
\text { the infarcted } \\
\text { myocardium }\end{array}$ & {$[23]$} \\
\hline Wt1+ & Wt1+; Is11+; Nkx2.5+ & $\begin{array}{l}\text { Wt1+ cells } \\
\text { contribute to } \\
\text { the whole heart } \\
\text { development by } \\
\text { lineage tracing } \\
\text { analysis }\end{array}$ & ND & ND & $\begin{array}{l}\mathrm{CMC} \\
\mathrm{EC}\end{array}$ & SMC; & $\begin{array}{ll}\text { CMC } & \text { markers; } \\
\text { sarcomere } & \text { markers; } \\
\text { action } & \text { potential; } \\
\text { calcium transient; } \\
\text { spontaneous } \\
\text { contraction }\end{array}$ & $\begin{array}{l}\text { Engrafted into } \\
\text { the infarcted } \\
\text { myocardium }\end{array}$ & {$[24,25]$} \\
\hline Cardiosphere & $\begin{array}{l}\text { Flk1+; cKit+; CD34+; } \\
\text { Sca1+; vWF+; } \\
\text { CD31low; cTnT+; } \\
\text { MHC+; CD105+ }\end{array}$ & ND & Yes & Yes & $\begin{array}{l}\mathrm{CMC} \text {; } \\
\mathrm{EC}\end{array}$ & SMC; & $\begin{array}{ll}\text { CMC } & \text { markers; } \\
\text { sarcomere } & \text { markers; } \\
\text { action } & \text { potential; } \\
\text { calcium } & \text { transient; } \\
\text { spontaneous } & \\
\text { contraction } & \\
\end{array}$ & $\begin{array}{l}\text { Function } \\
\text { improvement } \\
\text { of the } \\
\text { infarcted } \\
\text { heart with } \\
\text { regeneration }\end{array}$ & {$[26]$} \\
\hline
\end{tabular}

CMC: Cardiomyocyte; SMC: Smooth Muscle Cell; EC: Endothelial Cell; ND: Not Determined

\section{c-Kit ${ }^{+}$Lin- population}

The first report of purification and characterisation of CPCs was published in 2003 and defined as c-Kit ${ }^{+} \mathrm{Lin}^{-}$ cells [11]. To prove the existence of adult CPCs in the rat heart, Antonio et al. analysed three stem cell surface markers, including c-Kit, Sca1, and Flk1, which are commonly expressed by other adult stem cells. Immunohistological analysis showed that some c-Kit ${ }^{+} \mathrm{Lin}^{-}$, $\mathrm{Sca}^{+} \mathrm{Lin}^{-}$, and Flk1 $1^{+} \mathrm{Lin}^{-}$cells localised in the heart with a high nucleus/cytoplasm ratio. Finally, they focused on the c-Kit ${ }^{+} \mathrm{Lin}^{-}$population for further investigation because of the therapeutic effect of the $\mathrm{c}-\mathrm{Kit}^{+} \mathrm{Lin}^{-}$cell population in treating MI [27]. The purified c-Kit ${ }^{+} \mathrm{Lin}^{-}$cells were positive for cardiac markers Nkx2.5 and MEF2C, but negative for leukocyte marker CD45 and the hematopoietic progenitor marker CD34. They were self-renewing, clonogenic, and multi-potent, with the ability to differentiate into cardiomyocytes, endothelial cells, and smooth muscle cells both in vitro and in vivo. The cardiac regeneration role of c-kit ${ }^{+}$Lin $^{-}$cells in the animal model was proven to not result from cell fusion [11]. 
Table 2: Pre-clinical studies of CPC based cell therapy in heart diseases

\begin{tabular}{|c|c|c|c|c|c|c|}
\hline Cell source & $\begin{array}{l}\text { Animal } \\
\text { model/ } \\
\text { Species }\end{array}$ & Cell number & Route of delivery & Outcomes & Mechanism & Reference \\
\hline $\begin{array}{l}\text { Human } \\
\text { CPC }\end{array}$ & $\begin{array}{l}\text { MI / mice and } \\
\text { rat }\end{array}$ & $4 \times 10^{4}$ & Intramyocardial & $\begin{array}{l}\text { Attenuation of chamber dilation, } \\
\text { improvement of ventricular } \\
\text { function }\end{array}$ & CMC, EC, SMC differentiation & {$[31]$} \\
\hline $\begin{array}{l}\text { Autologous } \\
\text { cKit+ CPC }\end{array}$ & IR / pig & $5 \times 10^{5}$ & Intracoronary & $\begin{array}{l}\text { Improved LVEF, reduced LV end- } \\
\text { diastolic pressure }\end{array}$ & CMC, EC, SMC differentiation & {$[32]$} \\
\hline $\begin{array}{l}\text { Human } \\
\text { Cardiosphere }\end{array}$ & MI / mice & $1 \times 10^{5}$ & Intramyocardial & Improved LVEF & CMC, EC, SMC differentiation & {$[43]$} \\
\hline $\begin{array}{l}\text { Autologous } \\
\text { Cardiosphere }\end{array}$ & MI / pig & $1 \times 10^{7}$ & Intracoronary & $\begin{array}{l}\text { Decreased infarct size, improved } \\
\mathrm{dP} / \mathrm{dt}\end{array}$ & CMC differentiation & {$[37]$} \\
\hline $\begin{array}{l}\text { cKit+ } \quad \text { CPC } \\
\text { overexpressing } \\
\text { Pim-1 }\end{array}$ & $\mathrm{MI} /$ mice & $1 \times 10^{5}$ & Intramyocardial & $\begin{array}{l}\text { Reduced infarct size, increased } \\
\text { vasculature, improved LVEF }\end{array}$ & $\begin{array}{l}\text { Recruitment of endogenous } \\
\text { stem cells; increased CMC proliferation; } \\
\text { decreased apoptotic cell death; CMC, } \\
\text { EC, SMC differentiation }\end{array}$ & {$[33]$} \\
\hline $\begin{array}{l}\text { Human } \\
\text { cardiosphere }\end{array}$ & MI / mice & $\begin{array}{l}10 \text { spheres / } \\
\text { animal }\end{array}$ & Intramyocardial & $\begin{array}{l}\text { Preserved wall thickness, } \\
\text { improved fractional shortening }\end{array}$ & CMC, EC, SMC differentiation & {$[26]$} \\
\hline Rat cardiosphere & IR / rat & $1 \times 10^{6}$ & Intracoronary & $\begin{array}{l}\text { Improved left ventricular function, } \\
\text { reduced fibrosis }\end{array}$ & $\begin{array}{l}\text { Proliferation of endogenous CPCs; } \\
\text { CMC, EC, SMC differentiation }\end{array}$ & {$[45]$} \\
\hline $\begin{array}{l}\text { Mouse } \\
\text { cardiosphere }\end{array}$ & $\mathrm{MI} /$ mice & $2 \times 10^{5}$ & Intramyocardial & $\begin{array}{l}\text { Decreased scar size, increased } \\
\text { viable myocardium, improved } \\
\text { cardiac function }\end{array}$ & $\begin{array}{l}\text { Stimulated resident cardiomyocyte } \\
\text { cycling; recruitment of endogenous } \\
\text { CPC; CMC, EC, SMC differentiation }\end{array}$ & {$[40]$} \\
\hline Rat cardiosphere & MI / rat & $2 \times 10^{6}$ & Intramyocardial & $\begin{array}{l}\text { Reduced scar size and collagen } \\
\text { content, increased in viable mass, } \\
\text { improved left ventricular function }\end{array}$ & $\begin{array}{l}\text { Increased expression of the regenerative } \\
\text { growth factors: VEGF, HGF and } \\
\text { insulin-like growth factor-1; stimulated } \\
\text { angiogenesis; attenuated inflammatory } \\
\text { response; reduced proinflammatory } \\
\text { cytokines }\end{array}$ & {$[46]$} \\
\hline $\begin{array}{l}\text { Human } \\
\text { cardiosphere }\end{array}$ & MI / mice & $1 \times 10^{5}$ & Intramyocardial & Improved LVEF & $\begin{array}{l}\text { Secreted VEGF, HGF and insulin- } \\
\text { like growth factor 1; increased the } \\
\text { expression of Akt; decreased apoptotic } \\
\text { rate and caspase } 3 \text { level; increased } \\
\text { capillary density; CMC, EC, SMC } \\
\text { differentiation; recruiting endogenous } \\
\text { CPC and improving tissue resistance to } \\
\text { ischemic stress }\end{array}$ & {$[35]$} \\
\hline $\mathrm{cKit}+\mathrm{CPC}$ & MI / rat & $1 \times 10^{5}$ & Intramyocardial & $\begin{array}{l}\text { Reduced Infarct size, increased } \\
\text { capillaries density, improved } \\
\text { LVEF, reduced cavitary dilation, } \\
\text { increased wall thickness, } \\
\text { improved LV ejection fraction } \\
\text { and dP/dt }\end{array}$ & CMC, EC, SMC differentiation & {$[11]$} \\
\hline $\begin{array}{l}\text { Rat } \\
\text { Cardiosphere }\end{array}$ & IR / rat & $1 \times 10^{6}$ & Intracoronary & $\begin{array}{l}\text { Attenuated LV dilation, increased } \\
\text { wall thickness, decreased infarct } \\
\text { size }\end{array}$ & SMC EC differentiation & {$[36]$} \\
\hline $\begin{array}{l}\text { Rat } \\
\text { Cardiosphere }\end{array}$ & MI / rat & $4 \times 10^{4}$ & Intramyocardial & $\begin{array}{l}\text { Attenuated ventricular dilation, } \\
\text { prevented the chronic decline in } \\
\text { function, improved LVEF }\end{array}$ & $\begin{array}{l}\text { CMC differentiation, synthesize matrix } \\
\text { metalloproteinase, cytokines secretion }\end{array}$ & {$[79]$} \\
\hline $\begin{array}{l}\text { Autologous } \\
\text { Cardiosphere }\end{array}$ & MI / pig & $1 \times 10^{7}$ & Intramyocardial & $\begin{array}{l}\text { Improved ejection fraction, } \\
\text { attenuated adverse remodeling }\end{array}$ & Not addressed & {$[38]$} \\
\hline $\begin{array}{l}\text { Human } \\
\text { Cardiosphere }\end{array}$ & MI / mice & $1 \times 10^{5}$ & Intramyocardial & $\begin{array}{l}\text { Improved LVEF and wall } \\
\text { thickness, reduced infarct size }\end{array}$ & $\begin{array}{l}\text { CMC, EC, SMC differentiation; reduced } \\
\text { apoptotic cells; elevated cytokines } \\
\text { secretion }\end{array}$ & {$[39]$} \\
\hline $\begin{array}{l}\text { Human } \\
\text { Cardiosphere }\end{array}$ & MI / pig & $2 \times 10^{7}$ & Intramyocardial & $\begin{array}{l}\text { Improved LVEF, reduced infarct } \\
\text { size }\end{array}$ & heart regeneration, $\mathrm{CMC}$ differentiation & {$[44]$} \\
\hline $\begin{array}{l}\text { Mouse } \quad \mathrm{cKit}+ \\
\mathrm{CPC}\end{array}$ & $\begin{array}{l}\text { Acute heart } \\
\text { failure / mice }\end{array}$ & $5 \times 10^{5}$ & Tail-vein & Improved LV fraction shortening & $\begin{array}{l}\text { cardiac regeneration, } \\
\text { differentiation }\end{array}$ & {$[34]$} \\
\hline $\begin{array}{l}\text { Mouse Sca1+/ } \\
\text { CD31- CPC }\end{array}$ & MI / mice & $1 \times 10^{6}$ & Intramyocardial & $\begin{array}{l}\text { Attenuated adverse structural } \\
\text { remodeling, increased LVEF, } \\
\text { increased neovascularization }\end{array}$ & CMC, EC differentiation & {$[80]$} \\
\hline $\begin{array}{l}\text { Human } \\
\text { cardiosphere }\end{array}$ & MI / mice & $1 \times 10^{7}$ & Intramyocardial & $\begin{array}{l}\text { Preserved myocardial function, } \\
\text { prevented adverse remodeling, } \\
\text { and enhanced blood vessel } \\
\text { preservation }\end{array}$ & CMC, EC differentiation & {$[42]$} \\
\hline
\end{tabular}

CPC: cardiac progenitor cell; MI: myocardial infarction; IR: ischemia re-perfusion; LV: left ventricular; LVEF: left ventricular ejection fraction; CMC: cardiomyocyte; EC: endothelial cell; SMC: smooth muscle cell 


\section{Flk1 ${ }^{+}$population}

By using the GFP (Green Fluorescent Protein)-Bry mouse embryonic stem cell (mESC) line, in which GFP is expressed under the brachyury (Bry) promoter, it has been demonstrated that a $\mathrm{GFP}^{+} / \mathrm{Flk}^{+}$cell population during mESC differentiation has the ability to differentiate into beating cardiomyocytes in vitro. $\mathrm{GFP}^{+} / \mathrm{Flk}^{+}$cells express cardiac progenitor markers (Mesp1, Isl1, and Nkx2.5) with clonogenic capability and can also be differentiated into endothelial cells and smooth muscle cells. To determine whether this cell population exist in vivo, different regions and different stages of mouse embryos were cultured in vitro, and it was found that the colonies generated from anterior neural plate embryos and head-fold-stage embryos could become beating colonies. Of these, the head-fold-stage embryos produced more beating colonies. Then, the Flk1 ${ }^{+}$cells were purified from the head-foldstage embryos and they had the ability to differentiate into cardiomyocytes, endothelial cells, and smooth muscle cells $[13,14]$. This strategy was also applied to human ESC and a similar Flk1 ${ }^{+}$cell population with cardiac differentiation abilities (cardiomyocytes, endothelial cells, and smooth muscle cells) was discovered [13, 14].

\section{Sca $1^{+}$population}

Oh et al. analysed the stem cell markers Sca1 and c-Kit in adult mouse cardiac cells, in which the cardiomyocytes were depleted via enzyme digestion. It was found that $14-17 \%$ of them were Sca ${ }^{+}$. The Sca $1^{+}$cells did not express blood cell lineage markers, hematopoietic
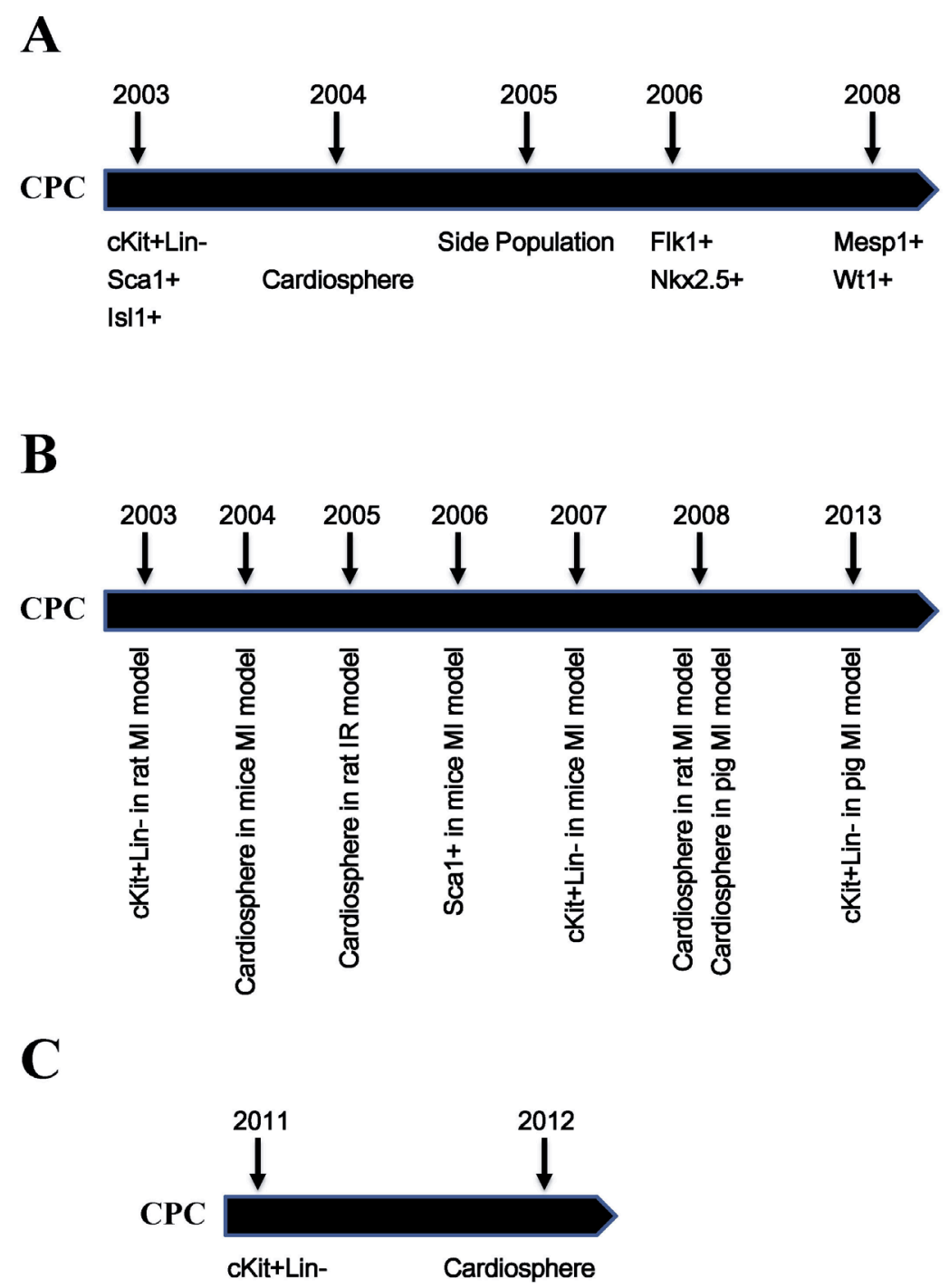

Figure 1: Timeline of the discovery of CPCs and their applications. A. Timeline of the discovery of different populations of CPCs. B. Timeline of the pre-clinical studies of CPCs. C. Timeline of the clinical studies of CPCs. CPC: cardiac progenitor cell; MI: myocardial infarction; IR: ischemia reperfusion. 
stem cell markers, or endothelial cell markers. They expressed cardiogenic genes, but not mature cardiac structural genes. After cardiomyocyte differentiation, they started to express mature cardiac structural genes. By using a lineage tracing system, the transplanted $\mathrm{Sca}^{+}$cells were recruited into the infarct region in a mouse MI model and expressed cardiomyocytes markers [15].

\section{Side population}

Side population cells are defined by their capacity to efflux Hoechst dye through an ATP (Adenosine Triphosphate)-binding cassette transporter. After depleting the cardiomyocytes, there was a population of Hoechstlow cells existing in the mouse heart-derived cells. The cardiac side population cells are capable of self-renewal and differentiating functional cardiomyocytes with spontaneous contracting $[16,17]$. And the Hoechst efflux ability of cardiac side population cells was completely inhibited by the ATP-binding cassette transporter inhibitor. They were negative for CD45, CD34, CD44, and c-Kit, but positive for CD31 and Sca1. The cardiac side population cells formed colonies, indicating their multi-potency characteristics. And their cardiomyocytes derivatives coupled with adult cardiomyocytes in vitro via the co-culture system without cell fusion events [16, 17]. Under physiologic conditions, the cardiac side population cells maintained their cell pool through cell proliferation without recruiting extra-cardiac stem cells. After MI, the cardiac side population cells were depleted quickly, and then the cell pool was reconstituted later through cell proliferation and recruiting stem cells from bone marrow $[16,17]$.

\section{Mesp1 $^{+}$population}

Mesp1 is the earliest marker in heart development, and almost all of the heart and related vessels are developed

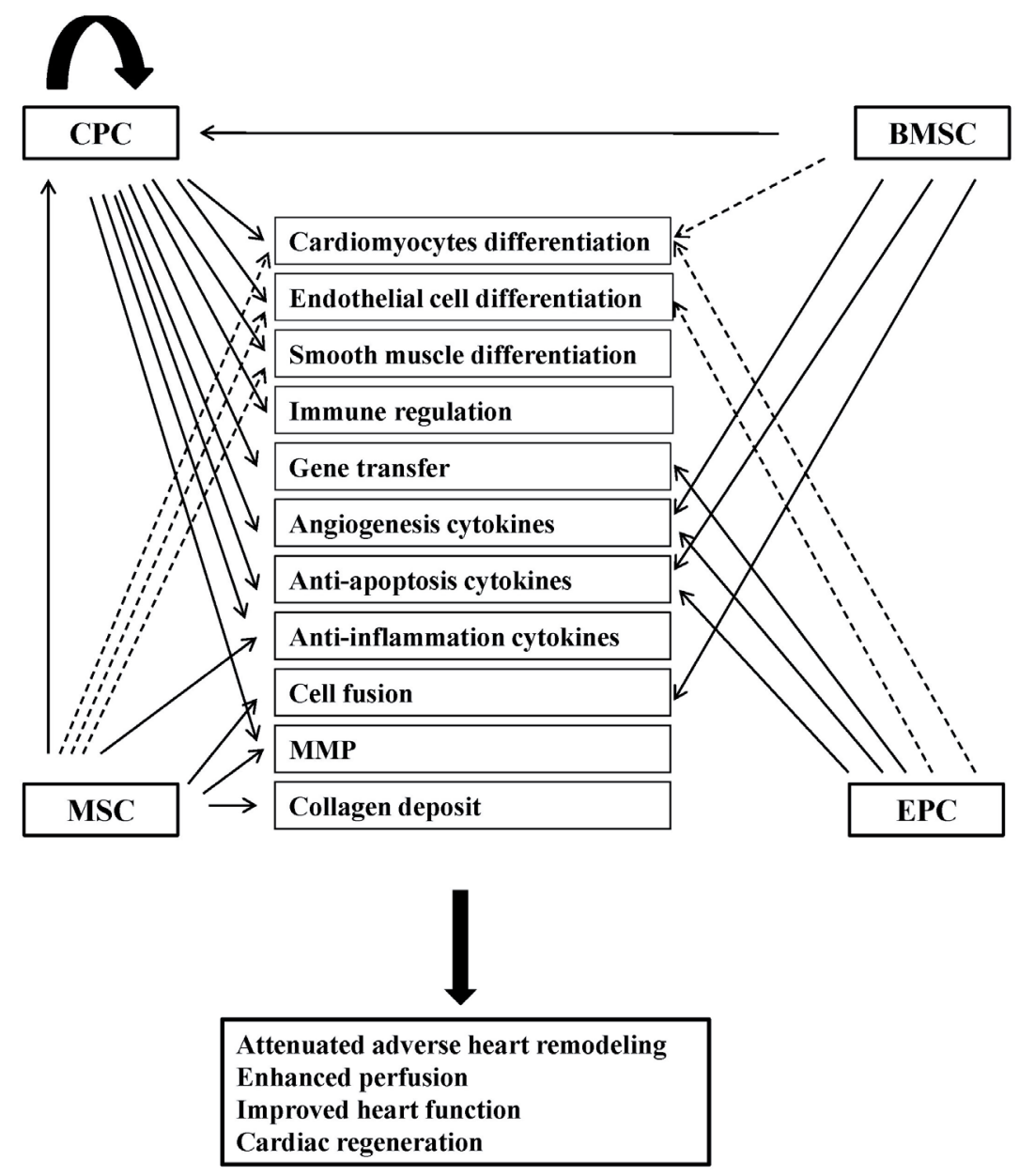

Figure 2: Potential mechanisms of stem cell therapy for myocardial infarction. The potential mechanisms have been proposed as direct cardiac differentiation (cardiomyocytes, endothelial cells and smooth muscle cells), paracrine effects (immune regulation, gene transfer, angiogenesis cytokines, anti-apoptosis cytokines, anti-inflammation cytokines, MMP, collagen deposit), and cell fusion. CPC: cardiac progenitor cell; BMSC: bone marrow stem cell; MSC: mesenchymal stem cell; EPC: endothelial progenitor cell; MMP: matrix metalloproteinase. Dash lines indicate that the evidences are controversial. 
Table 3: Clinical studies of CPC-based cell therapy in heart diseases

\begin{tabular}{|c|c|c|c|c|c|c|}
\hline Cell source & Cell number & Disease & Route of delivery & Outcomes & Mechanism & Reference \\
\hline Autologous cKit $+\mathrm{CPC}$ & $5-10 \times 105$ & $\mathrm{MI}(n=20)$ & Intracoronary & $\begin{array}{l}\text { Improved LVEF, decreased infarct size } \\
\text { at } 4 \text { months and } 1 \text { year }\end{array}$ & Not addressed & {$[51]$} \\
\hline Autologous cKit $+\mathrm{CPC}$ & $1 \times 106$ & $\operatorname{MI}(n=16)$ & Intracoronary & $\begin{array}{l}\text { Improved LVEF, decreased infarct size } \\
\text { at } 1 \text { year }\end{array}$ & Not addressed & {$[52]$} \\
\hline $\begin{array}{l}\text { Autologous } \\
\text { cardiospheres }\end{array}$ & $2-3 \times 106$ & $\begin{array}{l}\text { Hypoplastic left heart } \\
\text { syndrome }(n=7)\end{array}$ & Intracoronary & $\begin{array}{l}\text { Improved LVEF, reduced heart failure } \\
\text { status and increased viable tissue at } 18 \\
\text { and } 36 \text { months }\end{array}$ & Not addressed & {$[53,56]$} \\
\hline $\begin{array}{l}\text { Autologous } \\
\text { cardiospheres }\end{array}$ & $12.5-25 \times 106$ & $\operatorname{MI}(n=17)$ & Intracoronary & $\begin{array}{l}\text { Improved LVEF, decreased scar mass } \\
\text { and increased viable tissue at } 1 \text { year }\end{array}$ & Not addressed & {$[54,55]$} \\
\hline
\end{tabular}

CPC: cardiac progenitor cell; MI: myocardial infarction; LVEF: left ventricular ejection fraction.

from the Mesp $1^{+}$cells through lineage tracing studies [18, 19]. Transient expression of Mesp1 dramatically enhanced $\mathrm{CPC}$ generation and also cardiomyocyte differentiation in mouse ESC. Through whole-genome expression profiling and chromatin immunoprecipitation (ChIP) analysis, it has been shown that Mesp1 could directly upregulate cardiac transcription factors, such as Hand2 and Nkx2.5, and the Wnt pathway. In addition, Mesp1 suppressed the expression of genes related to pluripotent, endoderm, and early mesoderm $[18,19]$. Then, the ESC cell line with GFP expression driven by the Mesp1 promoter was established to purify the Mesp $1^{+}$cells. The purified Mesp $1^{+}$cells enriched CPCs with abilities to differentiate into cardiomyocytes, endothelial cells, and smooth muscle cells. Transplanting these Mesp $1^{+}$cells into the kidney capsule of immunodeficient mice showed that they mainly differentiated into cardiomyocytes in vivo and, to a lesser extent, endothelial cells and smooth muscle cells $[18,19]$.

\section{Isl1 $^{+}$population}

Isl1 is a transcription factor modulating heart development; lack of Isl1 results in heart abnormalities [20-22]. Using a lineage tracing strategy, the Is $11^{+}$cells represent a new population of CPCs involved in heart development. Approximately $30-40 \%$ cardiomyocytes originated from Isl $1^{+}$cells during heart development. Purified $\mathrm{Is}^{+} 1^{+}$cells showed functional ability of cardiomyocyte differentiation [20-22]. Using the mouse ESC cell line, Isl1 ${ }^{+}$cells were further proven as a CPC population with the ability to differentiate in cardiomyocytes, endothelial cells, and smooth muscle cells [20-22].

\section{Nkx2.5 population}

By using transgenic mice with GFP expression driven by the cardiac-specific Nkx2.5 enhancer, it was demonstrated that $\mathrm{Nkx} 2.5$ expression overlapped partially with Isl1 and completely overlapped with the sarcomeric myosin heavy chain [23]. Isolated $\mathrm{Nkx} 2.5^{+}$cells from embryos showed cardiomyocyte, conduction system cell, and smooth muscle cell differentiation ability. Purified $\mathrm{Nkx} 2.5^{+}$cell during mouse ESC differentiation also showed cardiomyocyte and smooth muscle differentiation ability in vitro and in vivo [23]. These cells were positive for c-Kit and Sca1, but negative for hematopoietic and endothelial markers [23]. Later study also showed that NKX2.5 positive CPCs could be generated from human ESC [28].

\section{$\mathrm{Wt1}^{+}$population}

By knocking-in GFP after the gene Wt1 (Wilms tumour 1), it was demonstrated that one population of CPCs located within the epicardium expressed the transcription factor $\mathrm{Wt} 1$. The data showed that some of the $\mathrm{Wt}^{+}$cells migrated and differentiated into functional cardiomyocytes during heart development. The cardiomyocytes originated from $\mathrm{Wt}^{+}$progenitor cells were located in all four chambers of the heart. Furthermore, these progenitor cells originated from early CPCs that expressed Nkx2.5 and Isl1. The purified $\mathrm{Wt}^{+}$ cells also had the capability of differentiating into beating cardiomyocytes, endothelial cells, and smooth muscle cells $[24,25]$. The $\mathrm{Wt1}^{+}$CPCs were activated after MI or thymosin beta4. Transplanting these $\mathrm{Wt}^{+}{ }^{+}$cells into the heart after MI showed functional cardiomyocyte differentiation and integration into the resident myocardium $[24,25]$.

\section{Cardiosphere}

Cardiospheres are composed of sphere-forming cells isolated from human heart biopsy (atrial and ventricular) and mouse heart (embryo, fetal, and postnatal). These 
Table 4: Generation of induced CPC via somatic reprogramming

\begin{tabular}{|c|c|c|c|c|c|c|c|c|c|c|c|}
\hline $\begin{array}{l}\text { Purification } \\
\text { Approach }\end{array}$ & $\begin{array}{l}\text { Starting } \\
\text { Cell Type }\end{array}$ & $\begin{array}{l}\text { Transcription } \\
\text { Factors }\end{array}$ & $\begin{array}{l}\text { Growth } \\
\text { Factors or } \\
\text { Chemicals }\end{array}$ & $\begin{array}{l}\text { CPC } \\
\text { Marker } \\
\text { Expression }\end{array}$ & $\begin{array}{l}\text { Whole } \\
\text { Genome Gene } \\
\text { Expression } \\
\text { Profile }\end{array}$ & $\begin{array}{l}\text { Cardiac } \\
\text { Differentiation } \\
\text { In Vitro }\end{array}$ & \begin{tabular}{|l} 
Differentiated \\
Cardiomyocytes \\
Characterization
\end{tabular} & $\begin{array}{l}\text { Cardiac } \\
\text { Differentiation } \\
\text { In Vivo }\end{array}$ & $\begin{array}{l}\text { Therapeutic } \\
\text { Application in } \\
\text { MI model }\end{array}$ & $\begin{array}{l}\text { Tumor } \\
\text { Formation }\end{array}$ & References \\
\hline Cardiosphere & $\mathrm{MEF}, \mathrm{AEF}$ & $\begin{array}{l}\text { Sox } 2, \quad \text { Klf4, } \\
\text { Oct } 4\end{array}$ & BIO, OSM & $\begin{array}{l}\text { Mesp1, Is11, } \\
\text { Nkx2.5 }\end{array}$ & $\begin{array}{l}\text { Clustered with } \\
\text { endogenous } \\
\text { cardiosphere }\end{array}$ & $\mathrm{CMC}, \mathrm{EC}, \mathrm{SMC}$ & $\begin{array}{l}\text { Action potential, } \\
\text { Calcium transient, } \\
\text { Contractility }\end{array}$ & $\mathrm{CMC}, \mathrm{EC}$ & $\begin{array}{l}\text { Improved } \\
\text { heart function, } \\
\text { reduced infract } \\
\text { size, increased } \\
\text { capillary density }\end{array}$ & $\begin{array}{l}\text { Not detected } \\
\text { in } 12 \text { weeks }\end{array}$ & [129] \\
\hline Flk $1^{+}$PdgfR $\alpha^{*}$ & MEF, TTF & $\begin{array}{l}\text { Sox } 2, \quad \text { Klf4, } \\
\text { Oct } 4, \text { c-Myc }\end{array}$ & $\begin{array}{l}\text { BMP4, } \\
\text { Activin A, } \\
\text { CHIR99021, } \\
\text { SU5402 }\end{array}$ & $\begin{array}{l}\text { Flk1 } 1^{+} \text {PdgfR } \\
\alpha^{+}\end{array}$ & $\begin{array}{l}\text { Clustered with } \\
\text { ESC derived } \\
\text { CPC }\end{array}$ & $\mathrm{CMC}, \mathrm{EC}, \mathrm{SMC}$ & $\begin{array}{l}\text { Action potential, } \\
\text { Calcium transient, } \\
\text { Contractility }\end{array}$ & $\begin{array}{l}\text { CMC, } \\
\text { SMC }\end{array}$ & $\begin{array}{l}\text { Improved heart } \\
\text { function, }\end{array}$ & Not analyzed & [128] \\
\hline $\mathrm{Nkx} 2.5^{+}$ & $\begin{array}{l}\text { CF, LF, } \\
\text { TTF }\end{array}$ & $\begin{array}{l}\text { Mesp1, } \\
\text { Tbx5, Gata4, } \\
\text { Nkx2.5, } \\
\text { Baf60c }\end{array}$ & LIF, BIO & Nkx2.5, Irx4 & $\begin{array}{l}\text { Clustered with } \\
\text { ESC derived } \\
\text { CPC }\end{array}$ & $\mathrm{CMC}, \mathrm{EC}, \mathrm{SMC}$ & $\begin{array}{l}\text { CMC marker } \\
\text { expression without } \\
\text { beating }\end{array}$ & $\begin{array}{l}\text { CMC, } \\
\text { SMC }\end{array}$ & $\begin{array}{l}\text { Improved } \\
\text { survival }\end{array}$ & $\begin{array}{l}\text { Not detected } \\
\text { in } 4 \text { weeks }\end{array}$ & [130] \\
\hline
\end{tabular}

MEF: mouse embryonic fibroblast; AEF: adult mouse ear fibroblast; TTF: mouse tail-tip fibroblast; CF: mouse cardiac fibroblast; LF: mouse lung fibroblast; OSM: oncostatin M; ESC: mouse embryonic stem cell; CPC: cardiac progenitor cell; CMC: cardiomyocyte; EC: endothelial cell; SMC: smooth muscle cell.

sphere-forming cells originate from small, round, and phase-bright cells that migrated from the heart explants [26]. Cardiospheres generated from mouse heart could beat spontaneously after sphere formation. However, the human cardiospheres did not have this capability unless they were co-cultured with rat neonatal cardiomyocytes. Cardiospheres could attach onto fibronectin-coated plates. They formed spheres when growing on poly-Dlysine-coated plates. They contained Flk1, CD31, CD34, c-Kit and Sca1 positive cells. When transplanting these cardiospheres into the dorsal subcutaneous region or the heart after MI, they had the capability to differentiate into cardiomyocytes, endothelial cells, and smooth muscle cells in vivo [26]. Although the cardiac stem cell property of cardiospheres has been questioned [29], the cardiosphere concept has been widely accepted.

\section{PRE-CLINICAL AND CLINICAL STUDIES OF CARDIAC PROGENITOR CELLS}

The therapeutic potential of CPCs has been intensively studied in animal models [30]. And the safety and practicability are further demonstrated by clinical studies. Among all types of CPCs, only two of them are widely studied for their therapeutic application in treating MI, c-Kit ${ }^{+}$CPCs and cardiosphere-derived cells [31] (Figure 1, Table 2, Table 3 and Supplementary Table 1).

Transplanting the ${\mathrm{c}-\mathrm{Kit}^{+}}^{\mathrm{CPCs}}$ into animal models with injured hearts promoted myocardial regeneration, heart function improvement, adverse heart remodelling attenuation, and cell death reduction with cardiomyocytes differentiation (Table 2) [11, 32-35]. In addition to the role of improving heart function and cardiac cell differentiation, transplanting cardiospheres or cardiosphere-derived cells also showed the effects of anti-apoptotic, anti-fibrotic, activating endogenous CPCs, cytokine secretion, and inflammation modulation (Table 2) [26, 36-47]. Furthermore, transplanting the cardiospheres in the form of the sphere was more effective than the cardiosphere-derived cells, indicating that the threedimensional structure maintained the niche for stem cells [48]. Combing the MSCs with cardiosphere-derived cells also showed increased efficacy in improving heart function and cardiac regeneration [49-51].

Because of the promising results in pre-clinical animal models, clinical trials were conducted to assess the safety, efficacy, and feasibility of CPCs in treating patients (Table 3 and Supplementary Table 1) [52-57]. The first phase 1 clinical trial using CPCs was conducted to investigate their safety and feasibility. Autologous c-Kit ${ }^{+} /$ $\mathrm{Lin}^{-} \mathrm{CPCs}$ were harvested during coronary artery bypass graft surgery and then used to treat heart failure patients with intracoronary infusion. Heart function was improved as early as 4 months after cell transplantation, and this effect continued up to 1 year later. During this period, the control group did not show any evidence of functional improvement. Furthermore, after CPCs transplantation, infarct size decreased, ventricular mass increased, and no adverse effects were observed (Table 3) [52, 53].

Transplanting autologous cardiospheres also showed cardiac function improvement, scar size reduction without any adverse events and tumour formation, indicating their safety and feasibility (Table 3) [54-56]. The ongoing clinical trials are designed to further address the effectiveness, cell type, cell number, delivery strategy, time window, and other factors (Table 4).

\section{MECHANISMS OF CELL THERAPY AND THE KEY ROLE OF CARDIAC PROGENITOR CELLS}

Two goals should be achieved in MI treatment. The first is to prevent cardiomyocyte death and adverse heart remodelling. The second is to promote cardiac repair or regeneration and preserve and recover cardiac function. So far, the potential mechanisms of stem cell therapy for treating MI have been proposed as direct cardiomyocyte differentiation, blood vessel formation (endothelial and smooth muscle cell differentiation), cell 
fusion, and paracrine effects (endogenous CPC activation, neovascularisation, and apoptosis inhibition) (Figure 2) [7, $58]$.

The efficacy of BMSCs, MSCs, and EPCs in treating myocardial infarction is evident. However, the underlying mechanism is believed to be paracrine effects and cell fusion, but not direct cardiomyocyte differentiation [5863]. The paracrine effects include promoting angiogenesis [64-66], preventing apoptosis [67, 68], suppressing inflammation [69-73], modulating extracellular matrix dynamics [74] and transferring genes into the local cardiomyocytes [75]. However, there are some other studies that have argued that direct cardiomyocyte differentiation also contributes to improvement in heart function [42, 76-79].

CPCs also have shown effectiveness in improving heart function, increasing neovascularisation, reducing infarct size, and attenuating adverse remodelling. Differing from BMSCs, MSCs and EPCs, for which the paracrine effect is the main mechanism of heart function improvement, it has shown strong evidences of direct cardiac differentiation (cardiomyocytes, endothelial cells, and smooth muscle cells) of CPCs [11, 26, 32-41, 4347, 80, 81]. Furthermore, cardiosphere transplantation also shows paracrine effects (Table 2). For example, they secrete cytokines (such as vascular endothelial growth factor, hepatocyte growth factor and insulin-like growth factor), activate endogenous stem cells, decrease cell apoptosis, remodel extracellular matrix, and inhibit inflammation response [34, 36, 40, 41, 46, 47, 80].

In a rat $\mathrm{MI}$ model, the $\mathrm{c}-\mathrm{Kit}^{+} \mathrm{CPC}$ s migrated into the infarct region through collagen type I and type III bundles. Analysis of matrix metalloproteinases (MMP; responsible for degrading extracellular matrix) and its tissue inhibitors of MMP (TIMP) showed that CPCs transplantation strongly promoted the expression level of MMP2, MMP9, and MMP14, and inhibited TIMP4 expression. These data indicated that CPCs have invasive ability through modulating extracellular matrix [80]. Transplanted CPCs (c-Kit ${ }^{+} \mathrm{CPCs}$ and cardiospheres) continued to proliferate in vivo and activated endogenous CPCs [36, 41, 46]. Overexpression of Pim1 in $\mathrm{c}-\mathrm{Kit}^{+} \mathrm{CPC}$ (component of AKT pathway that showed cardiac-protective activity) further enhanced the activity of CPCs [34]. Furthermore, miRNA could be transferred from CPC to cardiomyocytes [82-86].

MI triggers the resident cardiomyocytes to reenter the cell cycle, up-regulating cell cycle-related genes. This effect was further amplified by cardiosphere transplantation [41]. Cardiosphere transplantation reduced pro-inflammatory cytokines (tumour necrosis factor- $\alpha$, interferon- $\gamma$, interleukin-6, and interleukin-1 $\beta$ ), which are normally activated by $\mathrm{MI}$, and produced regenerative growth factors (VEGF, Vascular Endothelial Growth Factor; HGF, Hepatocyte Growth Factor; and insulinlike growth factor) $[36,47]$. In a rat ischemia reperfusion
(IR) model, cardiosphere transplantation was effective in reducing heart injury only when the transplantation was conducted in 20 minutes, but not after 2 days [87]. Cardiospheres could reduce the infarct size and prevent cardiomyocyte death through reducing pro-inflammatory factor secretion and the number of $\mathrm{CD} 68^{+}$macrophages. Cardiosphere cells activated the macrophage polarization, shifting them away from M1 macrophages, resulting in a reduction of the inflammation response. Cardiospheres that activated M2 macrophages polarization showed antioxidative and anti-apoptotic effects, and transplanting them into the rat IR model showed a reduction in heart injury [87]. More interestingly, the cardiospheres had been shown to be much more effective than $\mathrm{c}-\mathrm{Kit}^{+} \mathrm{CPC}$ for improving heart function because they secreted more cytokines [40].

CPCs in cell therapy for MI are important not only because they could differentiate into cardiac cells (cardiomyocytes, endothelial cells, and smooth muscle cells) and are involved in cardiac function preservation and recovery but also because they mediate the efficacy of other types of stem cells (BMSCs and MSCs, Figure 2). Therefore, CPCs are the most important player in heart function recovery after MI [35]. MSCs and BMSCs could stimulate endogenous CPC proliferation and differentiation, and the activated CPCs contribute to cardiac function improvement after MI $[88,89]$. The cell mixture of MSCs and CPCs had a synergistic effect on treating MI [50]. And the cell hybrids through cell fusion of cardiac progenitors and MSCs showed better efficacy in myocardial repair. However, abolishing endogenous CPCs would eliminate the regeneration process [49].

Therefore, it is becoming much more obvious that the therapeutic effects of cell therapy for preventing adverse heart remodelling and promoting cardiac regeneration might work through cardiac progenitor activity. Accounting for cardiac differentiation abilities, the CPCs play a central role in cell therapy of MI (Figure 2).

\section{ENDOGENOUS CARDIAC PROGENITOR CELLS ARE NOT SUFFICIENT FOR MYOCARDIAL REGENERATION}

The fact that most survivors of MI would eventually develop and die from congestive heart failure makes it clear that although there is some level of cardiomyocyte turnover in the adult heart, it is not sufficient to compensate for the cell loss [63]. In mice, cardiomyocyte regeneration occurs at a very low rate, and this is decreased during ageing and increased after injury [90]. Furthermore, both cell number and cell activity of cardiomyocytes and CPCs decline during ageing [91]. Cardiospheres derived from neonatal human atrium are more cardiomyogenic and more effective in the improvement of heart function in the mouse MI model [43]. 
Therefore, the body could not regenerate the heart by itself after the MI. After MI, the heart is in a high-inflammatory, fibrotic, low-nutrient, and hypoxia environment, which impairs the function and efficacy of cardiomyocytes, bone marrow stem cells, and local CPCs. Isolated CPCs from the heart could be used for transplantation after expansion in vitro. Considering that the procedures for cardiac cell harvesting are invasive and would cause more injury to patients with MI, the generation of induced CPCs via somatic reprogramming from somatic cells, which are more easily available, is necessary.

\section{CELL FATE CONVERSION VIA SOMATIC REPROGRAMMING IN CARDIAC CELLS}

The embryo is developed in a temporal and spatial manner and is precisely controlled by cytokines and genes. Stem cells with differentiation abilities play a crucial role in the development process. Normally, the differentiation ability of stem cells would become more and more committed during development, and this process is difficult to reverse. Eventually, cells become terminally differentiated in different tissues with different characteristics and functions. This process is called cell fate determination. Long ago, people believed that once the cell fate is determined, it is difficult to change. However, this has been challenged with the development of somatic reprogramming technologies. Somatic reprogramming is used to convert the terminally differentiated somatic cells to a more progenitor cell state or even pluripotent stem cells state with more differentiation abilities [9295]. After the breakthrough in somatic reprogramming with the development of induced pluripotent stem cell (iPSC) technology, the somatic reprogramming field has grown rapidly $[96,97]$. iPSC are generated through overexpressing transcription factors (Sox2, Klf4, Oct4, and c-Myc), which are important for pluripotent stem cell maintenance, in terminal differentiated somatic cells, and this converts the somatic cells into pluripotent stem cells [98-101].

Since then, the strategy of cell fate conversion through transcription factor overexpression has been widely used in the generation of different types of stem cells and terminally differentiated cells from somatic cells. There are two approaches to achieving cell fate conversion, lineage-specific transcription factors and Yamanaka factors (Sox2, Klf4, Oct4, and c-Myc) [102104]. Cardiomyocytes could be generated through overexpressing cardiac-specific transcription factor (Gata4, Mef2c, and Tbx5 or cardiac microRNAs) [102, 105-125] or Yamanaka factors in fibroblast cells [111, 123] (Supplementary Table 2).

Although the mechanism of cardiac cell fate conversion still remains unclear, genome-wide gene expression profile analysis showed that the cell fate conversion process induced cardiac gene expression and silenced the fibroblast-related genes. Direct cardiomyocyte generation from fibroblasts through cardiac-specific factors, such as GTM (Gata4, Tbx5, and Mef2c), did not pass a CPC stage $[105,109,120,125]$. However, the combination of Sox2, Klf4, and Oct4 reprogrammed fibroblasts into cardiomyocytes through a CPC stage with Mesp1 and Isl1 expression [111, 123], indicating the possibility of generating induced CPCs from somatic cells via somatic programming.

\section{GENERATION OF INDUCED CARDIAC PROGENITOR CELLS VIA SOMATIC REPROGRAMMING}

The reprogrammed cardiomyocytes have very low conversion efficiency and no proliferation capacity. Therefore, expansion in vitro for transplantation is not feasible. The therapeutic application of this strategy only relies on reprogramming in vivo [106, 108, 110, 114]. In addition to the low conversion efficiency in vivo, disturbing the function of cardiac fibroblasts with virus and gene overexpression might also affect the regenerative effects of cardiac fibroblasts that play a central role in heart remodelling and regeneration [126-128]. Therefore, it is necessary to generate CPC-like stem cells with the ability to regenerate the heart which might provide an unlimited source of stem cells with cardiac differentiation potentials [129-131] (Table 4).

We developed a novel approach to generate induced cardiospheres (iCS) from adult skin fibroblasts via somatic reprogramming [130]. After infection with Sox2, Klf4 and Oct4, iCS were generated from mouse adult skin fibroblasts treated with Gsk3 $\beta$ inhibitor(2'Z, 3'E) - 6-Bromoindirubin-3'-oxime (BIO) and Oncostatin M. They resembled endogenous cardiospheres (eCS) with whole genome gene expression analysis, but contained a higher percentage of cells expressing Mesp1, Is11 and Nkx2.5. They were differentiated into functional cardiomyocytes in vitro with similar electrophysiological properties, calcium transient and contractile function to eCS and mouse embryonic stem cell-derived cardiomyocytes. Transplantation of iCS into mouse myocardium following MI had similar effects to transplantation of eCS but significantly better than saline or fibroblast in improving left ventricular ejection fraction, increasing anterior/septal ventricular wall thickness and capillary density in the infarcted region 4 weeks after transplantation [130].

Zhang et al. also found that the induced CPC (Flk $1^{+} \mathrm{PdgfR} \alpha^{+}$population) could be generated from mouse fibroblasts with overexpressing Sox2, Klf4, Oct4 and c-Myc plus BMP4, Activin A, CHIR99021 (GSK3beta inhibitor) and SU5402 (FGF, VEGF and PDGF inhibitor) stimulation [129]. The Flk1 ${ }^{+} \mathrm{PdgfR} \alpha^{+}$induced CPC 
(iCPC) could be expandable and differentiated into cardiomyocytes, endothelial cells and smooth muscle cells. The differentiated cardiomyocytes had functional action potential and calcium transient activities. They could be stimulated by caffeine and isoproterenol. Whole genome expression analysis showed that they are similar with ESC derived CPCs. Transplanting Flk $1^{+} \mathrm{PdgfR} \alpha^{+}$ iCPC into MI mice model improved heart function [129].

On the other hand, the iCPC could be generated through lineage specific transcription factors Mesp1, Tbx5, Gata4, Nkx2.5 and Baf60c (MTGNB) plus LIF (leukemia inhibitory factor) and BIO stimulation [131]. Using a mouse model containing Nkx2.5-EYFP (enhanced yellow fluorescent protein) reporter system, the Nkx2.5EYFP positive iCPC could be purified and expanded in vitro without expressing pluripotent markers. Whole genome expression analysis showed that they are similar with ESC derived CPCs. They could be differentiated into cardiomyocytes, endothelial cells and smooth muscle cells in vitro and cardiomyocytes in vivo. Transplanting these iCPC into MI mice model improved heart function without tumor formation [131].

\section{FUTURE PERSPECTIVES}

The iCPC could be generated from somatic cells via somatic reprogramming strategy with lineage specific transcription factors or Yamanaka factors overexpression. The Nkx $2.5^{+}$and Flk1 $1^{+} \mathrm{PdgfR} \alpha^{+} \mathrm{iCPC}$ are similar to mouse ESC derived CPCs, but whether they are also similar to endogenous CPCs or not remains unclear. The induced cardiosphere is similar to the endogenous cardiosphere but they both contain mixed cell populations, including CPCs and other supporting cells [132]. Therefore, more specific CPC surface markers and CPC purification methods should be developed. Furthermore, the iCPC are generated through a virus based method and the genome integration impairs their potential therapeutic applications. Thus integration-free methods should be applied in iCPC generation in the future.

\section{CONFLICTS OF INTEREST}

The authors declare that there are no conflicts of interest.

\section{FUNDING}

Novel technology development project of Shenzhen. No. CXZZ2015093105220591.

\section{REFERENCES}

1. Go AS, Mozaffarian D, Roger VL, Benjamin EJ, Berry JD, Borden WB, Bravata DM, Dai S, Ford ES, Fox CS, Franco
S, Fullerton HJ, Gillespie C, et al. Executive summary: heart disease and stroke statistics - 2013 update: a report from the American Heart Association. Circulation. 2013; 127:143-152.

2. Heusch G, Libby P, Gersh B, Yellon D, Bohm M, Lopaschuk G, Opie L. Cardiovascular remodelling in coronary artery disease and heart failure. Lancet. 2014; 383:1933-1943.

3. Willerson JT. Stem cell therapy for cardiovascular diseases: a progressive journey. Current opinion in cardiology. 2015.

4. Martin-Puig S, Wang Z, Chien KR. Lives of a heart cell: tracing the origins of cardiac progenitors. Cell stem cell. 2008; 2:320-331.

5. Segers VF, Lee RT. Stem-cell therapy for cardiac disease. Nature. 2008; 451:937-942.

6. Behfar A, Crespo-Diaz R, Terzic A, Gersh BJ. Cell therapy for cardiac repair-lessons from clinical trials. Nature reviews Cardiology. 2014; 11:232-246.

7. Sanganalmath SK, Bolli R. Cell therapy for heart failure: a comprehensive overview of experimental and clinical studies, current challenges, and future directions. Circulation research. 2013; 113:810-834.

8. Deutsch MA, Sturzu A, Wu SM. At a crossroad: cell therapy for cardiac repair. Circulation research. 2013; 112:884-890.

9. Menasche P, Hagege AA, Scorsin M, Pouzet B, Desnos M, Duboc D, Schwartz K, Vilquin JT, Marolleau JP. Myoblast transplantation for heart failure. Lancet. 2001; 357:279-280.

10. Zhang YM, Hartzell C, Narlow M, Dudley SC Jr. Stem cellderived cardiomyocytes demonstrate arrhythmic potential. Circulation. 2002; 106:1294-1299.

11. Beltrami AP, Barlucchi L, Torella D, Baker M, Limana F, Chimenti S, Kasahara H, Rota M, Musso E, Urbanek K, Leri A, Kajstura J, Nadal-Ginard B, et al. Adult cardiac stem cells are multipotent and support myocardial regeneration. Cell. 2003; 114:763-776.

12. Sturzu AC, Wu SM. Developmental and regenerative biology of multipotent cardiovascular progenitor cells. Circulation research. 2011; 108:353-364.

13. Kattman SJ, Huber TL, Keller GM. Multipotent flk$1+$ cardiovascular progenitor cells give rise to the cardiomyocyte, endothelial, and vascular smooth muscle lineages. Developmental cell. 2006; 11:723-732.

14. Yang L, Soonpaa MH, Adler ED, Roepke TK, Kattman SJ, Kennedy M, Henckaerts E, Bonham K, Abbott GW, Linden RM, Field LJ, Keller GM. Human cardiovascular progenitor cells develop from a KDR+ embryonic-stem-cell-derived population. Nature. 2008; 453:524-528.

15. Oh H, Bradfute SB, Gallardo TD, Nakamura T, Gaussin V, Mishina Y, Pocius J, Michael LH, Behringer RR, Garry DJ, Entman ML, Schneider MD. Cardiac progenitor cells from adult myocardium: homing, differentiation, and fusion after infarction. Proceedings of the National Academy of Sciences of the United States of America. 2003; 100:12313- 
12318.

16. Mouquet F, Pfister O, Jain M, Oikonomopoulos A, Ngoy $\mathrm{S}$, Summer R, Fine A, Liao R. Restoration of cardiac progenitor cells after myocardial infarction by selfproliferation and selective homing of bone marrow-derived stem cells. Circulation research. 2005; 97:1090-1092.

17. Pfister O, Mouquet F, Jain M, Summer R, Helmes M, Fine A, Colucci WS, Liao R. CD31- but Not CD31+ cardiac side population cells exhibit functional cardiomyogenic differentiation. Circulation research. 2005; 97:52-61.

18. Bondue A, Lapouge G, Paulissen C, Semeraro C, Iacovino M, Kyba M, Blanpain C. Mesp1 acts as a master regulator of multipotent cardiovascular progenitor specification. Cell stem cell. 2008; 3:69-84.

19. Bondue A, Tannler S, Chiapparo G, Chabab S, Ramialison M, Paulissen C, Beck B, Harvey R, Blanpain C. Defining the earliest step of cardiovascular progenitor specification during embryonic stem cell differentiation. The Journal of cell biology. 2011; 192:751-765.

20. Cai CL, Liang X, Shi Y, Chu PH, Pfaff SL, Chen J, Evans S. Isl1 identifies a cardiac progenitor population that proliferates prior to differentiation and contributes a majority of cells to the heart. Developmental cell. 2003; 5:877-889.

21. Laugwitz KL, Moretti A, Lam J, Gruber P, Chen Y, Woodard S, Lin LZ, Cai CL, Lu MM, Reth M, Platoshyn O, Yuan JX, Evans S, et al. Postnatal is11+ cardioblasts enter fully differentiated cardiomyocyte lineages. Nature. 2005; 433:647-653.

22. Moretti A, Caron L, Nakano A, Lam JT, Bernshausen A, Chen Y, Qyang Y, Bu L, Sasaki M, Martin-Puig S, Sun Y, Evans SM, Laugwitz KL, et al. Multipotent embryonic isl1+ progenitor cells lead to cardiac, smooth muscle, and endothelial cell diversification. Cell. 2006; 127:1151-1165.

23. Wu SM, Fujiwara Y, Cibulsky SM, Clapham DE, Lien CL, Schultheiss TM, Orkin SH. Developmental origin of a bipotential myocardial and smooth muscle cell precursor in the mammalian heart. Cell. 2006; 127:1137-1150.

24. Zhou B, Ma Q, Rajagopal S, Wu SM, Domian I, RiveraFeliciano J, Jiang D, von Gise A, Ikeda S, Chien KR, Pu WT. Epicardial progenitors contribute to the cardiomyocyte lineage in the developing heart. Nature. 2008; 454:109-113.

25. Smart N, Bollini S, Dube KN, Vieira JM, Zhou B, Davidson S, Yellon D, Riegler J, Price AN, Lythgoe MF, $\mathrm{Pu}$ WT, Riley PR. De novo cardiomyocytes from within the activated adult heart after injury. Nature. 2011; 474:640644.

26. Messina E, De Angelis L, Frati G, Morrone S, Chimenti S, Fiordaliso F, Salio M, Battaglia M, Latronico MV, Coletta M, Vivarelli E, Frati L, Cossu G, et al. Isolation and expansion of adult cardiac stem cells from human and murine heart. Circulation research. 2004; 95:911-921.

27. Orlic D, Kajstura J, Chimenti S, Jakoniuk I, Anderson SM, Li B, Pickel J, McKay R, Nadal-Ginard B, Bodine DM,
Leri A, Anversa P. Bone marrow cells regenerate infarcted myocardium. Nature. 2001; 410:701-705.

28. Elliott DA, Braam SR, Koutsis K, Ng ES, Jenny R, Lagerqvist EL, Biben C, Hatzistavrou T, Hirst CE, Yu QC, Skelton RJ, Ward-van Oostwaard D, Lim SM, et al. NKX2-5(eGFP/w) hESCs for isolation of human cardiac progenitors and cardiomyocytes. Nature methods. 2011; 8:1037-1040.

29. Andersen DC, Andersen P, Schneider M, Jensen HB, Sheikh SP. Murine "cardiospheres" are not a source of stem cells with cardiomyogenic potential. Stem cells. 2009; 27:1571-1581.

30. Samanta A, Dawn B. Meta-Analysis of Preclinical Data Reveals Efficacy of Cardiac Stem Cell Therapy for Heart Repair. Circulation research. 2016; 118:1186-1188.

31. Zwetsloot PP, Vegh AM, Jansen of Lorkeers SJ, van Hout GP, Currie GL, Sena ES, Gremmels H, Buikema JW, Goumans MJ, Macleod MR, Doevendans PA, Chamuleau SA, Sluijter JP. Cardiac Stem Cell Treatment in Myocardial Infarction: A Systematic Review and Meta-Analysis of Preclinical Studies. Circulation research. 2016; 118:12231232.

32. Bearzi C, Rota M, Hosoda T, Tillmanns J, Nascimbene A, De Angelis A, Yasuzawa-Amano S, Trofimova I, Siggins RW, Lecapitaine N, Cascapera S, Beltrami AP, D'Alessandro DA, et al. Human cardiac stem cells. Proceedings of the National Academy of Sciences of the United States of America. 2007; 104:14068-14073.

33. Bolli R, Tang XL, Sanganalmath SK, Rimoldi O, Mosna F, Abdel-Latif A, Jneid H, Rota M, Leri A, Kajstura J. Intracoronary delivery of autologous cardiac stem cells improves cardiac function in a porcine model of chronic ischemic cardiomyopathy. Circulation. 2013; 128:122-131.

34. Fischer KM, Cottage CT, Wu W, Din S, Gude NA, Avitabile D, Quijada P, Collins BL, Fransioli J, Sussman MA. Enhancement of myocardial regeneration through genetic engineering of cardiac progenitor cells expressing Pim-1 kinase. Circulation. 2009; 120:2077-2087.

35. Ellison GM, Vicinanza C, Smith AJ, Aquila I, Leone A, Waring CD, Henning BJ, Stirparo GG, Papait R, Scarfo M, Agosti V, Viglietto G, Condorelli G, et al. Adult c-kit(pos) cardiac stem cells are necessary and sufficient for functional cardiac regeneration and repair. Cell. 2013; 154:827-842.

36. Chimenti I, Smith RR, Li TS, Gerstenblith G, Messina E, Giacomello A, Marban E. Relative roles of direct regeneration versus paracrine effects of human cardiosphere-derived cells transplanted into infarcted mice. Circulation research. 2010; 106:971-980.

37. Dawn B, Stein AB, Urbanek K, Rota M, Whang B, Rastaldo R, Torella D, Tang XL, Rezazadeh A, Kajstura J, Leri A, Hunt G, Varma J, et al. Cardiac stem cells delivered intravascularly traverse the vessel barrier, regenerate infarcted myocardium, and improve cardiac function. Proceedings of the National Academy of Sciences of the United States of America. 2005; 102:3766-3771. 
38. Johnston PV, Sasano T, Mills K, Evers R, Lee ST, Smith RR, Lardo AC, Lai S, Steenbergen C, Gerstenblith G, Lange R, Marban E. Engraftment, differentiation, and functional benefits of autologous cardiosphere-derived cells in porcine ischemic cardiomyopathy. Circulation. 2009; 120:1075-1083, $1077 \mathrm{p}$ following 1083.

39. Lee ST, White AJ, Matsushita S, Malliaras K, Steenbergen C, Zhang Y, Li TS, Terrovitis J, Yee K, Simsir S, Makkar $\mathrm{R}$, Marban E. Intramyocardial injection of autologous cardiospheres or cardiosphere-derived cells preserves function and minimizes adverse ventricular remodeling in pigs with heart failure post-myocardial infarction. Journal of the American College of Cardiology. 2011; 57:455-465.

40. Li TS, Cheng K, Malliaras K, Smith RR, Zhang Y, Sun B, Matsushita N, Blusztajn A, Terrovitis J, Kusuoka H, Marban L, Marban E. Direct comparison of different stem cell types and subpopulations reveals superior paracrine potency and myocardial repair efficacy with cardiospherederived cells. Journal of the American College of Cardiology. 2012; 59:942-953.

41. Malliaras K, Zhang Y, Seinfeld J, Galang G, Tseliou E, Cheng K, Sun B, Aminzadeh M, Marban E. Cardiomyocyte proliferation and progenitor cell recruitment underlie therapeutic regeneration after myocardial infarction in the adult mouse heart. EMBO Mol Med. 2013; 5:191-209.

42. Rota M, Kajstura J, Hosoda T, Bearzi C, Vitale S, Esposito G, Iaffaldano G, Padin-Iruegas ME, Gonzalez A, Rizzi R, Small N, Muraski J, Alvarez R, et al. Bone marrow cells adopt the cardiomyogenic fate in vivo. Proceedings of the National Academy of Sciences of the United States of America. 2007; 104:17783-17788.

43. Simpson DL, Mishra R, Sharma S, Goh SK, Deshmukh S, Kaushal S. A strong regenerative ability of cardiac stem cells derived from neonatal hearts. Circulation. 2012; 126:S46-53.

44. Smith RR, Barile L, Cho HC, Leppo MK, Hare JM, Messina E, Giacomello A, Abraham MR, Marban E. Regenerative potential of cardiosphere-derived cells expanded from percutaneous endomyocardial biopsy specimens. Circulation. 2007; 115:896-908.

45. Takehara N, Tsutsumi Y, Tateishi K, Ogata T, Tanaka H, Ueyama T, Takahashi T, Takamatsu T, Fukushima M, Komeda M, Yamagishi M, Yaku H, Tabata Y, et al. Controlled delivery of basic fibroblast growth factor promotes human cardiosphere-derived cell engraftment to enhance cardiac repair for chronic myocardial infarction. Journal of the American College of Cardiology. 2008; 52:1858-1865.

46. Tang XL, Rokosh G, Sanganalmath SK, Yuan F, Sato H, Mu J, Dai S, Li C, Chen N, Peng Y, Dawn B, Hunt G, Leri A, et al. Intracoronary administration of cardiac progenitor cells alleviates left ventricular dysfunction in rats with a 30-day-old infarction. Circulation. 2010; 121:293-305.

47. Tseliou E, Pollan S, Malliaras K, Terrovitis J, Sun B, Galang G, Marban L, Luthringer D, Marban E. Allogeneic cardiospheres safely boost cardiac function and attenuate adverse remodeling after myocardial infarction in immunologically mismatched rat strains. Journal of the American College of Cardiology. 2013; 61:1108-1119.

48. Li TS, Cheng K, Lee ST, Matsushita S, Davis D, Malliaras K, Zhang Y, Matsushita N, Smith RR, Marban E. Cardiospheres recapitulate a niche-like microenvironment rich in stemness and cell-matrix interactions, rationalizing their enhanced functional potency for myocardial repair. Stem cells. 2010; 28:2088-2098.

49. Quijada P, Salunga HT, Hariharan N, Cubillo J, El-Sayed F, Moshref M, Bala KM, Emathinger JM, De La Torre A, Ormachea L, Alvarez R, Gude NA, Sussman MA. Cardiac Stem Cell Hybrids Enhance Myocardial Repair. Circulation research. 2015.

50. Williams AR, Hatzistergos KE, Addicott B, McCall F, Carvalho D, Suncion V, Morales AR, Da Silva J, Sussman MA, Heldman AW, Hare JM. Enhanced effect of combining human cardiac stem cells and bone marrow mesenchymal stem cells to reduce infarct size and to restore cardiac function after myocardial infarction. Circulation. 2013; 127:213-223.

51. Zakharova L, Mastroeni D, Mutlu N, Molina M, Goldman S, Diethrich E, Gaballa MA. Transplantation of cardiac progenitor cell sheet onto infarcted heart promotes cardiogenesis and improves function. Cardiovascular research. 2010; 87:40-49.

52. Chugh AR, Beache GM, Loughran JH, Mewton N, Elmore JB, Kajstura J, Pappas P, Tatooles A, Stoddard MF, Lima JA, Slaughter MS, Anversa P, Bolli R. Administration of cardiac stem cells in patients with ischemic cardiomyopathy: the SCIPIO trial: surgical aspects and interim analysis of myocardial function and viability by magnetic resonance. Circulation. 2012; 126:S54-64.

53. Bolli R, Chugh AR, D'Amario D, Loughran JH, Stoddard MF, Ikram S, Beache GM, Wagner SG, Leri A, Hosoda T, Sanada F, Elmore JB, Goichberg P, et al. Cardiac stem cells in patients with ischaemic cardiomyopathy (SCIPIO): initial results of a randomised phase 1 trial. Lancet. 2011; 378:1847-1857.

54. Ishigami S, Ohtsuki S, Tarui S, Ousaka D, Eitoku T, Kondo M, Okuyama M, Kobayashi J, Baba K, Arai S, Kawabata T, Yoshizumi K, Tateishi A, et al. Intracoronary autologous cardiac progenitor cell transfer in patients with hypoplastic left heart syndrome: the TICAP prospective phase 1 controlled trial. Circulation research. 2015; 116:653-664.

55. Makkar RR, Smith RR, Cheng K, Malliaras K, Thomson LE, Berman D, Czer LS, Marban L, Mendizabal A, Johnston PV, Russell SD, Schuleri KH, Lardo AC, et al. Intracoronary cardiosphere-derived cells for heart regeneration after myocardial infarction (CADUCEUS): a prospective, randomised phase 1 trial. Lancet. 2012; 379:895-904.

56. Malliaras K, Makkar RR, Smith RR, Cheng K, Wu E, Bonow RO, Marban L, Mendizabal A, Cingolani E, 
Johnston PV, Gerstenblith G, Schuleri KH, Lardo AC, et al. Intracoronary cardiosphere-derived cells after myocardial infarction: evidence of therapeutic regeneration in the final 1-year results of the CADUCEUS trial (CArdiosphereDerived aUtologous stem CElls to reverse ventricUlar dySfunction). Journal of the American College of Cardiology. 2014; 63(2):110-122.

57. Tarui S, Ishigami S, Ousaka D, Kasahara S, Ohtsuki S, Sano $\mathrm{S}, \mathrm{Oh} \mathrm{H}$. Transcoronary infusion of cardiac progenitor cells in hypoplastic left heart syndrome: Three-year follow-up of the Transcoronary Infusion of Cardiac Progenitor Cells in Patients With Single-Ventricle Physiology (TICAP) trial. J Thorac Cardiovasc Surg. 2015; 150:1198-1207, 1208 e1191-1192.

58. Gnecchi M, Zhang Z, Ni A, Dzau VJ. Paracrine mechanisms in adult stem cell signaling and therapy. Circulation research. 2008; 103:1204-1219.

59. Balsam LB, Wagers AJ, Christensen JL, Kofidis T, Weissman IL, Robbins RC. Haematopoietic stem cells adopt mature haematopoietic fates in ischaemic myocardium. Nature. 2004; 428:668-673.

60. Murry CE, Soonpaa MH, Reinecke H, Nakajima H, Nakajima HO, Rubart M, Pasumarthi KB, Virag JI, Bartelmez SH, Poppa V, Bradford G, Dowell JD, Williams DA, et al. Haematopoietic stem cells do not transdifferentiate into cardiac myocytes in myocardial infarcts. Nature. 2004; 428:664-668.

61. Nygren JM, Jovinge S, Breitbach M, Sawen P, Roll W, Hescheler J, Taneera J, Fleischmann BK, Jacobsen SE. Bone marrow-derived hematopoietic cells generate cardiomyocytes at a low frequency through cell fusion, but not transdifferentiation. Nature medicine. 2004; 10:494-501.

62. Gnecchi M, He H, Liang OD, Melo LG, Morello F, Mu H, Noiseux N, Zhang L, Pratt RE, Ingwall JS, Dzau VJ. Paracrine action accounts for marked protection of ischemic heart by Akt-modified mesenchymal stem cells. Nature medicine. 2005; 11:367-368.

63. Hayashi E, Hosoda T. Myocyte renewal and therapeutic myocardial regeneration using various progenitor cells. Heart failure reviews. 2014; 19:789-797.

64. Pober JS, Min W, Bradley JR. Mechanisms of endothelial dysfunction, injury, and death. Annual review of pathology. 2009; 4:71-95.

65. Fazel S, Cimini M, Chen L, Li S, Angoulvant D, Fedak P, Verma S, Weisel RD, Keating A, Li RK. Cardioprotective c-kit+ cells are from the bone marrow and regulate the myocardial balance of angiogenic cytokines. The Journal of clinical investigation. 2006; 116:1865-1877.

66. Zeng L, Hu Q, Wang X, Mansoor A, Lee J, Feygin J, Zhang G, Suntharalingam P, Boozer S, Mhashilkar A, Panetta CJ, Swingen C, Deans R, et al. Bioenergetic and functional consequences of bone marrow-derived multipotent progenitor cell transplantation in hearts with postinfarction left ventricular remodeling. Circulation. 2007; 115:18661875 .
67. Xu JY, Lee YK, Wang Y, Tse HF. Therapeutic application of endothelial progenitor cells for treatment of cardiovascular diseases. Current stem cell research \& therapy. 2014; 9:401-414.

68. Iekushi K, Seeger F, Assmus B, Zeiher AM, Dimmeler $\mathrm{S}$. Regulation of cardiac microRNAs by bone marrow mononuclear cell therapy in myocardial infarction. Circulation. 2012; 125:1765-1773, S1761-1767.

69. Psaltis PJ, Zannettino AC, Worthley SG, Gronthos S. Concise review: mesenchymal stromal cells: potential for cardiovascular repair. Stem cells. 2008; 26:2201-2210.

70. Williams AR, Hare JM. Mesenchymal stem cells: biology, pathophysiology, translational findings, and therapeutic implications for cardiac disease. Circulation research. 2011; 109:923-940.

71. Nombela-Arrieta C, Ritz J, Silberstein LE. The elusive nature and function of mesenchymal stem cells. Nature reviews Molecular cell biology. 2011; 12:126-131.

72. Karantalis V and Hare JM. Use of mesenchymal stem cells for therapy of cardiac disease. Circulation research. 2015; 116:1413-1430.

73. Lee RH, Pulin AA, Seo MJ, Kota DJ, Ylostalo J, Larson BL, Semprun-Prieto L, Delafontaine P, Prockop DJ. Intravenous hMSCs improve myocardial infarction in mice because cells embolized in lung are activated to secrete the anti-inflammatory protein TSG-6. Cell stem cell. 2009; 5:54-63.

74. Mias C, Lairez O, Trouche E, Roncalli J, Calise D, Seguelas MH, Ordener C, Piercecchi-Marti MD, Auge N, Salvayre AN, Bourin P, Parini A, Cussac D. Mesenchymal stem cells promote matrix metalloproteinase secretion by cardiac fibroblasts and reduce cardiac ventricular fibrosis after myocardial infarction. Stem cells. 2009; 27:2734-2743.

75. Burghoff S, Ding Z, Godecke S, Assmann A, Wirrwar A, Buchholz D, Sergeeva O, Leurs C, Hanenberg H, Muller HW, Bloch W, Schrader J. Horizontal gene transfer from human endothelial cells to rat cardiomyocytes after intracoronary transplantation. Cardiovascular research. 2008; 77:534-543.

76. Kajstura J, Rota M, Whang B, Cascapera S, Hosoda T, Bearzi C, Nurzynska D, Kasahara H, Zias E, Bonafe M, Nadal-Ginard B, Torella D, Nascimbene A, et al. Bone marrow cells differentiate in cardiac cell lineages after infarction independently of cell fusion. Circulation research. 2005; 96:127-137.

77. Thal MA, Krishnamurthy P, Mackie AR, Hoxha E, Lambers E, Verma S, Ramirez V, Qin G, Losordo DW, Kishore R. Enhanced angiogenic and cardiomyocyte differentiation capacity of epigenetically reprogrammed mouse and human endothelial progenitor cells augments their efficacy for ischemic myocardial repair. Circulation research. 2012; 111:180-190.

78. Condorelli G, Borello U, De Angelis L, Latronico M, Sirabella D, Coletta M, Galli R, Balconi G, Follenzi A, 
Frati G, Cusella De Angelis MG, Gioglio L, Amuchastegui $\mathrm{S}$, et al. Cardiomyocytes induce endothelial cells to trans-differentiate into cardiac muscle: implications for myocardium regeneration. Proceedings of the National Academy of Sciences of the United States of America. 2001; 98:10733-10738.

79. Badorff C, Brandes RP, Popp R, Rupp S, Urbich C, Aicher A, Fleming I, Busse R, Zeiher AM, Dimmeler S. Transdifferentiation of blood-derived human adult endothelial progenitor cells into functionally active cardiomyocytes. Circulation. 2003; 107:1024-1032.

80. Rota M, Padin-Iruegas ME, Misao Y, De Angelis A, Maestroni S, Ferreira-Martins J, Fiumana E, Rastaldo R, Arcarese ML, Mitchell TS, Boni A, Bolli R, Urbanek K, et al. Local activation or implantation of cardiac progenitor cells rescues scarred infarcted myocardium improving cardiac function. Circulation research. 2008; 103:107-116.

81. Wang X, Hu Q, Nakamura Y, Lee J, Zhang G, From AH, Zhang J. The role of the sca-1+/CD31- cardiac progenitor cell population in postinfarction left ventricular remodeling. Stem cells. 2006; 24:1779-1788.

82. Das S, Halushka MK. Extracellular vesicle microRNA transfer in cardiovascular disease. Cardiovascular pathology. 2015; 24:199-206.

83. McManus DD, Freedman JE. MicroRNAs in platelet function and cardiovascular disease. Nature reviews Cardiology. 2015.

84. Dangwal S, Thum T. microRNA therapeutics in cardiovascular disease models. Annual review of pharmacology and toxicology. 2014; 54:185-203.

85. Quiat D, Olson EN. MicroRNAs in cardiovascular disease: from pathogenesis to prevention and treatment. The Journal of clinical investigation. 2013; 123:11-18.

86. Hata A. Functions of microRNAs in cardiovascular biology and disease. Annual review of physiology. 2013; 75:69-93.

87. de Couto G, Liu W, Tseliou E, Sun B, Makkar N, Kanazawa H, Arditi M, Marban E. Macrophages mediate cardioprotective cellular postconditioning in acute myocardial infarction. The Journal of clinical investigation. 2015; 125:3147-3162.

88. Hatzistergos KE, Quevedo H, Oskouei BN, Hu Q, Feigenbaum GS, Margitich IS, Mazhari R, Boyle AJ, Zambrano JP, Rodriguez JE, Dulce R, Pattany PM, Valdes D, et al. Bone marrow mesenchymal stem cells stimulate cardiac stem cell proliferation and differentiation. Circulation research. 2010; 107:913-922.

89. Loffredo FS, Steinhauser ML, Gannon J, Lee RT. Bone marrow-derived cell therapy stimulates endogenous cardiomyocyte progenitors and promotes cardiac repair. Cell stem cell. 2011; 8:389-398.

90. Senyo SE, Steinhauser ML, Pizzimenti CL, Yang VK, Cai L, Wang M, Wu TD, Guerquin-Kern JL, Lechene CP, Lee RT. Mammalian heart renewal by pre-existing cardiomyocytes. Nature. 2013; 493:433-436.
91. Torella D, Rota M, Nurzynska D, Musso E, Monsen A, Shiraishi I, Zias E, Walsh K, Rosenzweig A, Sussman MA, Urbanek K, Nadal-Ginard B, Kajstura J, et al. Cardiac stem cell and myocyte aging, heart failure, and insulin-like growth factor-1 overexpression. Circulation research. 2004; 94:514-524.

92. Gurdon JB. From nuclear transfer to nuclear reprogramming: the reversal of cell differentiation. Annu Rev Cell Dev Biol. 2006; 22:1-22.

93. Wilmut I, Beaujean N, de Sousa PA, Dinnyes A, King TJ, Paterson LA, Wells DN, Young LE. Somatic cell nuclear transfer. Nature. 2002; 419:583-586.

94. Cowan CA, Atienza J, Melton DA, Eggan K. Nuclear reprogramming of somatic cells after fusion with human embryonic stem cells. Science. 2005; 309:1369-1373.

95. Noggle S, Fung HL, Gore A, Martinez H, Satriani KC, Prosser R, Oum K, Paull D, Druckenmiller S, Freeby M, Greenberg E, Zhang K, Goland R, et al. Human oocytes reprogram somatic cells to a pluripotent state. Nature. 2011; 478:70-75.

96. Takahashi K, Yamanaka S. Induction of pluripotent stem cells from mouse embryonic and adult fibroblast cultures by defined factors. Cell. 2006; 126:663-676.

97. Takahashi K, Tanabe K, Ohnuki M, Narita M, Ichisaka T, Tomoda K, Yamanaka S. Induction of pluripotent stem cells from adult human fibroblasts by defined factors. Cell. 2007; 131:861-872.

98. Buganim Y, Faddah DA, Jaenisch R. Mechanisms and models of somatic cell reprogramming. Nat Rev Genet. 2013; 14:427-439.

99. Nishikawa S, Goldstein RA, Nierras CR. The promise of human induced pluripotent stem cells for research and therapy. Nature reviews Molecular cell biology. 2008; 9:725-729.

100. Robinton DA, Daley GQ. The promise of induced pluripotent stem cells in research and therapy. Nature. 2012; 481:295-305.

101. Yamanaka S. Induced pluripotent stem cells: past, present, and future. Cell stem cell. 2012; 10:678-684.

102. Fu JD, Srivastava D. Direct reprogramming of fibroblasts into cardiomyocytes for cardiac regenerative medicine. Circulation journal : official journal of the Japanese Circulation Society. 2015; 79:245-254.

103. Sadahiro T, Yamanaka S, Ieda M. Direct cardiac reprogramming: progress and challenges in basic biology and clinical applications. Circulation research. 2015; 116:1378-1391.

104. Sahara M, Santoro F, Chien KR. Programming and reprogramming a human heart cell. The EMBO journal. 2015; 34:710-738.

105. Ieda M, Fu JD, Delgado-Olguin P, Vedantham V, Hayashi Y, Bruneau BG, Srivastava D. Direct reprogramming of fibroblasts into functional cardiomyocytes by defined factors. Cell. 2010; 142:375-386. 
106. Inagawa K, Miyamoto K, Yamakawa H, Muraoka N, Sadahiro T, Umei T, Wada R, Katsumata Y, Kaneda R, Nakade K, Kurihara C, Obata Y, Miyake K, et al. Induction of cardiomyocyte-like cells in infarct hearts by gene transfer of Gata4, Mef2c, and Tbx5. Circulation research. 2012; 111:1147-1156.

107. Qian L, Huang Y, Spencer CI, Foley A, Vedantham V, Liu L, Conway SJ, Fu JD, Srivastava D. In vivo reprogramming of murine cardiac fibroblasts into induced cardiomyocytes. Nature. 2012.

108. Song K, Nam YJ, Luo X, Qi X, Tan W, Huang GN, Acharya A, Smith CL, Tallquist MD, Neilson EG, Hill JA, Bassel-Duby R, Olson EN. Heart repair by reprogramming non-myocytes with cardiac transcription factors. Nature. 2012; 485:599-604.

109. Wada R, Muraoka N, Inagawa K, Yamakawa H, Miyamoto K, Sadahiro T, Umei T, Kaneda R, Suzuki T, Kamiya K, Tohyama S, Yuasa S, Kokaji K, et al. Induction of human cardiomyocyte-like cells from fibroblasts by defined factors. Proceedings of the National Academy of Sciences of the United States of America. 2013; 110:12667-12672.

110. Jayawardena TM, Egemnazarov B, Finch EA, Zhang L, Payne JA, Pandya K, Zhang Z, Rosenberg P, Mirotsou M, Dzau VJ. MicroRNA-Mediated In Vitro and In Vivo Direct Reprogramming of Cardiac Fibroblasts to Cardiomyocytes. Circulation research. 2012.

111. Efe JA, Hilcove S, Kim J, Zhou H, Ouyang K, Wang G, Chen J, Ding S. Conversion of mouse fibroblasts into cardiomyocytes using a direct reprogramming strategy. Nature cell biology. 2011; 13:215-222.

112. Kim TK, Sul JY, Peternko NB, Lee JH, Lee M, Patel VV, Kim J, Eberwine JH. Transcriptome transfer provides a model for understanding the phenotype of cardiomyocytes. Proceedings of the National Academy of Sciences of the United States of America. 2011; 108:11918-11923.

113. Islas JF, Liu Y, Weng KC, Robertson MJ, Zhang S, Prejusa A, Harger J, Tikhomirova D, Chopra M, Iyer D, Mercola M, Oshima RG, Willerson JT, et al. Transcription factors ETS2 and MESP1 transdifferentiate human dermal fibroblasts into cardiac progenitors. Proceedings of the National Academy of Sciences of the United States of America. 2012; 109:13016-13021.

114. Mathison M, Gersch RP, Nasser A, Lilo S, Korman M, Fourman M, Hackett N, Shroyer K, Yang J, Ma Y, Crystal $\mathrm{RG}$, Rosengart TK. In vivo cardiac cellular reprogramming efficacy is enhanced by angiogenic preconditioning of the infarcted myocardium with vascular endothelial growth factor. Journal of the American Heart Association. 2012; $1: \mathrm{e} 005652$.

115. Protze S, Khattak S, Poulet C, Lindemann D, Tanaka EM, Ravens U. A new approach to transcription factor screening for reprogramming of fibroblasts to cardiomyocyte-like cells. Journal of molecular and cellular cardiology. 2012; 53:323-332.

116. Addis RC, Ifkovits JL, Pinto F, Kellam LD, Esteso P,
Rentschler S, Christoforou N, Epstein JA, Gearhart JD. Optimization of direct fibroblast reprogramming to cardiomyocytes using calcium activity as a functional measure of success. Journal of molecular and cellular cardiology. 2013; 60:97-106.

117. Christoforou N, Chellappan M, Adler AF, Kirkton RD, Wu T, Addis RC, Bursac N, Leong KW. Transcription factors MYOCD, SRF, Mesp1 and SMARCD3 enhance the cardioinducing effect of GATA4, TBX5, and MEF2C during direct cellular reprogramming. PLoS One. 2013; 8:e63577.

118. Fu JD, Stone NR, Liu L, Spencer CI, Qian L, Hayashi Y, Delgado-Olguin P, Ding S, Bruneau BG,Srivastava D. Direct reprogramming of human fibroblasts toward a cardiomyocyte-like state. Stem Cell Reports. 2013; 1:235247.

119. Hirai H, Katoku-Kikyo N, Keirstead SA, Kikyo N. Accelerated direct reprogramming of fibroblasts into cardiomyocyte-like cells with the MyoD transactivation domain. Cardiovascular research. 2013; 100:105-113.

120. Nam YJ, Song K, Luo X, Daniel E, Lambeth K, West K, Hill JA, DiMaio JM, Baker LA, Bassel-Duby R, Olson EN. Reprogramming of human fibroblasts toward a cardiac fate. Proceedings of the National Academy of Sciences of the United States of America. 2013; 110:5588-5593.

121. Ifkovits JL, Addis RC, Epstein JA, Gearhart JD. Inhibition of TGFbeta signaling increases direct conversion of fibroblasts to induced cardiomyocytes. PLoS One. 2014; 9:e89678.

122. Muraoka N, Yamakawa H, Miyamoto K, Sadahiro T, Umei $\mathrm{T}$, Isomi $\mathrm{M}$, Nakashima $\mathrm{H}$, Akiyama $\mathrm{M}$, Wada R, Inagawa K, Nishiyama T, Kaneda R, Fukuda T, et al. MiR-133 promotes cardiac reprogramming by directly repressing Snail and silencing fibroblast signatures. The EMBO journal. 2014; 33:1565-1581.

123. Wang H, Cao N, Spencer CI, Nie B, Ma T, Xu T, Zhang Y, Wang X, Srivastava D, Ding S. Small Molecules Enable Cardiac Reprogramming of Mouse Fibroblasts with a Single Factor, Oct4. Cell reports. 2014.

124. Jayawardena TM, Finch EA, Zhang L, Zhang $\mathrm{H}$, Hodgkinson CP, Pratt RE, Rosenberg PB, Mirotsou M, Dzau VJ. MicroRNA induced cardiac reprogramming in vivo: evidence for mature cardiac myocytes and improved cardiac function. Circulation research. 2015; 116:418-424.

125. Wang L, Liu Z, Yin C, Asfour H, Chen O, Li Y, Bursac N, Liu J, Qian L. Stoichiometry of Gata4, Mef2c, and Tbx5 influences the efficiency and quality of induced cardiac myocyte reprogramming. Circulation research. 2015; 116:237-244.

126. Lighthouse JK, Small EM. Transcriptional control of cardiac fibroblast plasticity. Journal of molecular and cellular cardiology. 2015; 91:52-60.

127. Shinde AV, Frangogiannis NG. Fibroblasts in myocardial infarction: a role in inflammation and repair. Journal of molecular and cellular cardiology. 2014; 70:74-82. 
128. van den Borne SW, Diez J, Blankesteijn WM, Verjans J, Hofstra L,Narula J. Myocardial remodeling after infarction: the role of myofibroblasts. Nature reviews Cardiology. 2010; 7:30-37.

129. Zhang Y, Cao N, Huang Y, Spencer CI, Fu JD, Yu C, Liu K, Nie B, Xu T, Li K, Xu S, Bruneau BG, Srivastava $\mathrm{D}$, et al. Expandable Cardiovascular Progenitor Cells Reprogrammed from Fibroblasts. Cell stem cell. 2016; 18:368-381.

130. Xu JY, Lee YK, Ran X, Liao SY, Yang J, Au KW, Lai WH, Esteban MA, Tse HF. Generation of Induced Cardiospheres via Reprogramming of Skin Fibroblasts for Myocardial Regeneration. Stem cells. 2016.
131. Lalit PA, Salick MR, Nelson DO, Squirrell JM, Shafer CM, Patel NG, Saeed I, Schmuck EG, Markandeya YS, Wong R, Lea MR, Eliceiri KW, Hacker TA, et al. Lineage Reprogramming of Fibroblasts into Proliferative Induced Cardiac Progenitor Cells by Defined Factors. Cell stem cell. 2016; 18:354-367.

132. Mishra R, Vijayan K, Colletti EJ, Harrington DA, Matthiesen TS, Simpson D, Goh SK, Walker BL, AlmeidaPorada G, Wang D, Backer CL, Dudley SC Jr., Wold LE, et al. Characterization and functionality of cardiac progenitor cells in congenital heart patients. Circulation. 2011; 123:364-373. 